OECDpublishing

\title{
MEASURING \\ PLATFORM \\ MEDIATED \\ WORKERS
}

OECD DIGITAL ECONOMY PAPERS

April 2019 No. 282 


\section{Foreword}

This paper, prepared by the CDEP Secretariat in cooperation with the Directorate of Employment, Labour and Social Affairs (DELSA), builds on the 2016 OECD technical report 'New Forms of Work in the Digital Economy' prepared for the Cancún Ministerial. Since 2016, there have been a large number of initiatives to estimate the number of platform-mediated workers, both by private institutions and national statistical offices. The paper reviews the results of these initiatives and suggests future approaches for the number of platform workers, their characteristics, and the characteristics of their jobs and tasks.

The report was approved and declassified by written procedure by the Committee on Digital Economy Policy on 16 November 2018 and was prepared for publication by the OECD Secretariat.

This report was drafted by Rory O'Farrell and Pierre Montagnier from the OECD Secretariat. The authors are grateful for the contributions of Duncan MacDonald and comments and suggestions by Stijn Broecke and Vincenzo Spiezia.

Note to Delegations:

This document is also available on O.N.E. under the reference code:

DSTI/CDEP/MADE(2018)7/FINAL

This document, as well as any data and any map included herein, are without prejudice to the status of or sovereignty over any territory, to the delimitation of international frontiers and boundaries and to the name of any territory, city or area.

\section{OECD 2019}

You can copy, download or print OECD content for your own use, and you can include excerpts from OECD publications, databases and multimedia products in your own documents, presentations, blogs, websites and teaching materials, provided that suitable acknowledgement of OECD as source and copyright owner is given. All requests for commercial use and translation rights should be submitted to rights@oecd.org. 


\section{Table of contents}

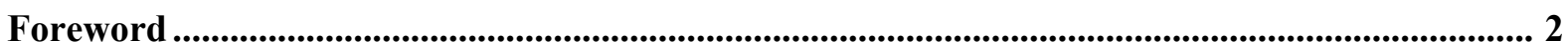

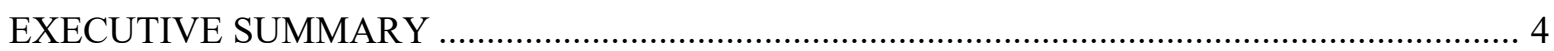

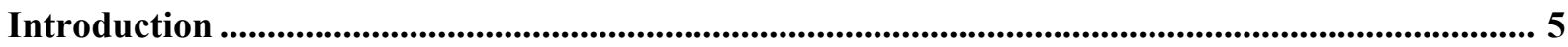

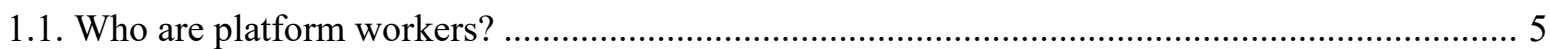

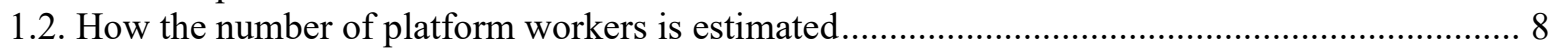

1.2.1. Early estimates of platform workers varied widely.......................................................... 8

1.2.2. There have been some attempts by statistical agencies of OECD Member States.................14

1.3. Alternative data sources can give a richer understanding of platform workers ..........................20

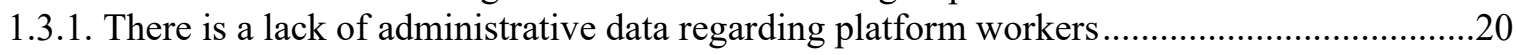

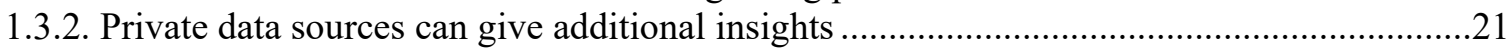

1.3.3. Data from platforms can also give insights into general labour market problems .................22

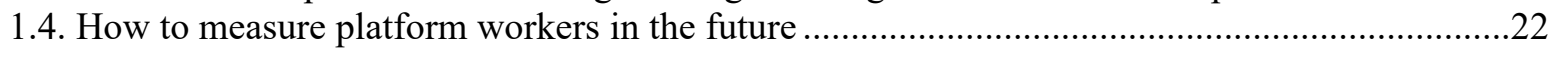

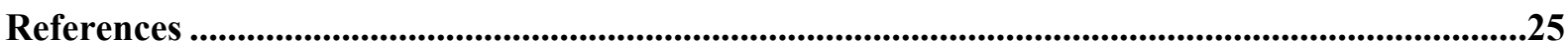

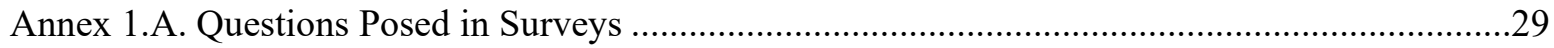

\section{Tables}

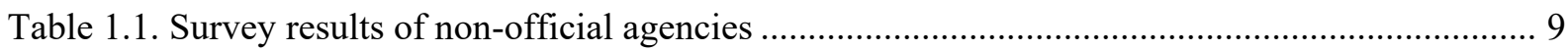

Table 1.2. The concept of platform worker used and survey results vary across official surveys ..........15

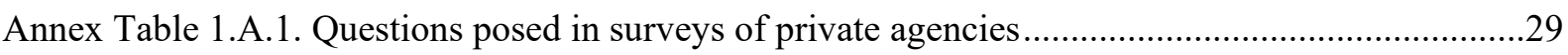

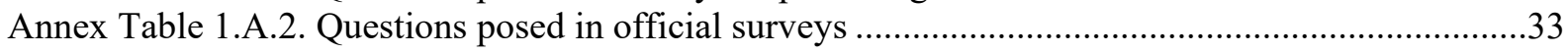

Figures

Figure 1.1. Use of mobile internet rapidly expanded following introduction of smartphones............... 6

Figure 1.2. There is a wide variety of platform services ................................................................... 7

Figure 1.3. There is wide variation in participation in platform work across countries .........................13

Figure 1.4. Differences in concepts and definitions lead tolittle consistency across estimates..............14

Figure 1.5. New vacancies listed on the top 5 English-language online working platforms.................22 


\section{EXECUTIVE SUMMARY}

The role of digital platform workers, whether they are delivering fast-food or working remotely categorising photographs, has received much attentions both in the media and among policy makers. Providing good policy advice requires good data and, as of yet, there is a lack of comparable and consistent statistics, over time and across countries, on the number of platform workers, their characteristics, and the characteristics of their jobs and tasks.

There have been several attempts to estimate the number of platform workers. Initial attempts made use of existing data sources, combined with strong assumptions, and led to varying estimates of the size of the platform economy. Since then, official statistical agencies of OECD Members have begun to introduce questions on platform workers into labour force surveys and Internet usage surveys with wide variation in results; (though typically in the range of about $0.5 \%$ to $2 \%$ ). These efforts highlight some of the difficulties in measuring platform workers.

Firstly, there are difficulties in explaining to survey respondents what is meant by platform work. Many respondents report being platform workers due to the poorly definitions presented to them, such as if they make use of a computer or mobile app in their job. Adjusting for obviously incorrect responses can considerably reduce the estimated number of platform workers. Second, there are inconsistencies across countries in how platform workers are measured. For example, some surveys do not differentiate between capital and labour platforms. The vast majority of surveys use the last 12 months as the reference period, whereas others use a reference week (in order to be consistent with labour force survey results). Finally, most estimates of the number of platform workers are in the range of $0.5 \%$ to $2 \%$. This leads to small a sample sizes, limiting how precisely we can estimate the characteristics of platform workers, such as gender or occupation.

Although the problem of sample size can be overcome through the use of administrative data, such as social security or tax data, administrative data has shortcomings that affects the measurement of platform workers. For example, workers may be below VAT reporting thresholds. Nevertheless, partnerships between government agencies and online platforms to improve tax collection have the potential to improve administrative data sources. For example, in France, from 2019 online platforms will be obliged to report an individual's annual gross income to the tax authorities.

Potential next steps could include collaborative work to formulate standard questions for inclusion in surveys. More experimentation in terms of ordering of questions and use of prompting questions may be necessary before such questions are included in surveys. It is also necessary to decide upon the appropriate survey for different topics: for example, an ICT usage survey may be appropriate for questions regarding the service provided (such as whether services are delivered physically or online), but inappropriate for questions regarding hours worked or whether platform work is a person's primary or secondary job. 


\section{Introduction}

In August 2018 New York City banned new ride hailing licences for a year, following on from a temporary ban of Uber in London in 2017. However, while work platforms are visible in the headlines, there is, as of yet, a lack of comparable and consistent statistics on the number of platform workers, their characteristics, and the characteristics of their jobs and tasks across countries and over time.

This paper builds on the 2016 OECD technical report 'New Forms of Work in the Digital Economy' by putting forward some recommendations for future approaches to measuring platform workers $($ OECD, 2016 $[1])$. Since 2016, there has been a large number of attempts to estimate the number of platform workers, including attempts by official statistical agencies. However there have been difficulties in conveying to survey respondents what is meant by platform work. The paper begins by explaining the concept of platform work. Section 1.2 looks at the attempts to measure platform workers by private agencies, and official statistical agencies, and examines how differently formulated survey questions can affect the understanding of the respondent. Section 1.3 highlights innovative uses of data that provide greater insights into platform workers. Section 1.4 concludes by recommending ways to measure platform workers in the future.

\subsection{Who are platform workers?}

Platform workers use an app or a website to match with customers in order to provide a service (rather than goods) in return for money. They offer a diverse range of services including ride hailing, coding, and writing product descriptions. Platform work may be a worker's main job, or occasional secondary work to supplement a worker's income. While the notion is clear, there is currently no accepted standard definition of platform work. Platform work is related to terms such as the gig economy and sharing economy. However, the 'gig economy' is usually considered broader in scope, and predates the invention of online (or digital) platforms and the Internet, having its origins in musicians playing one-off concerts or gigs. In addition, although the sharing economy has similarities such as the matching of service providers and customers through online platforms, the sharing economy generally refers to matching of assets with customers rather than labour (Office of National Statistics, 2017 $[2]$ ).

Online platforms have been defined as "a digital service that facilitates interactions between two or more distinct but interdependent sets of users who interact through the service via the Internet" (OECD, 2019 $\left.{ }_{[3]}\right)$. The use of an app forms an integral part of providing the service, for instance allowing the worker to submit their work (such as product descriptions) through the platform, or making payments through the platform. This integral use of the platform differentiates work platforms from traditional labour market intermediaries such as employment agencies and employment websites where a platform establishes the initial contact between the job seeker and the potential employer, but plays no role thereafter. 
Online work platforms also differ from employment websites in that the platform typically matches workers with customers in order to complete a task or project, rather than form an ongoing relationship. The worker may complete the task or project in a relatively short time in the case of microwork, or may be more long-term in nature for freelancers. Whether the role of a digital intermediary goes beyond a mere matching of workers and customers and there is in fact an employer-employee relationship with the worker, is not discussed in this paper (see for example: (OECD, 2018 ${ }_{[4]}$; OECD, 2019 ${ }_{[5]}$; Hunter and Leslie, 2018[6])).

Advances in digital technology have enabled the emergence of online platform work (Figure 1.1). Technology such as smartphones' geo-location features have improved the efficiency of matching of workers and customers for previously existing services (such as ride hailing), while providing ratings of past work can help a customer find an appropriate worker. In addition, entirely new jobs performed online such as categorising the data of websites and testing apps (sometimes referred to as click work) have emerged. Meanwhile, practices associated with platform work (such as the use of an app to notify workers of their working hours, or websites for logging work) are being used by traditional employers, blurring the distinction between the two (Huws, Spencer and Syrdal, 2018 $[7])$.

Figure 1.1. Use of mobile internet rapidly expanded following introduction of smartphones

Data and voice mobile broadband subscriptions per 100 inhabitants in OECD countries, 2009 and 2017

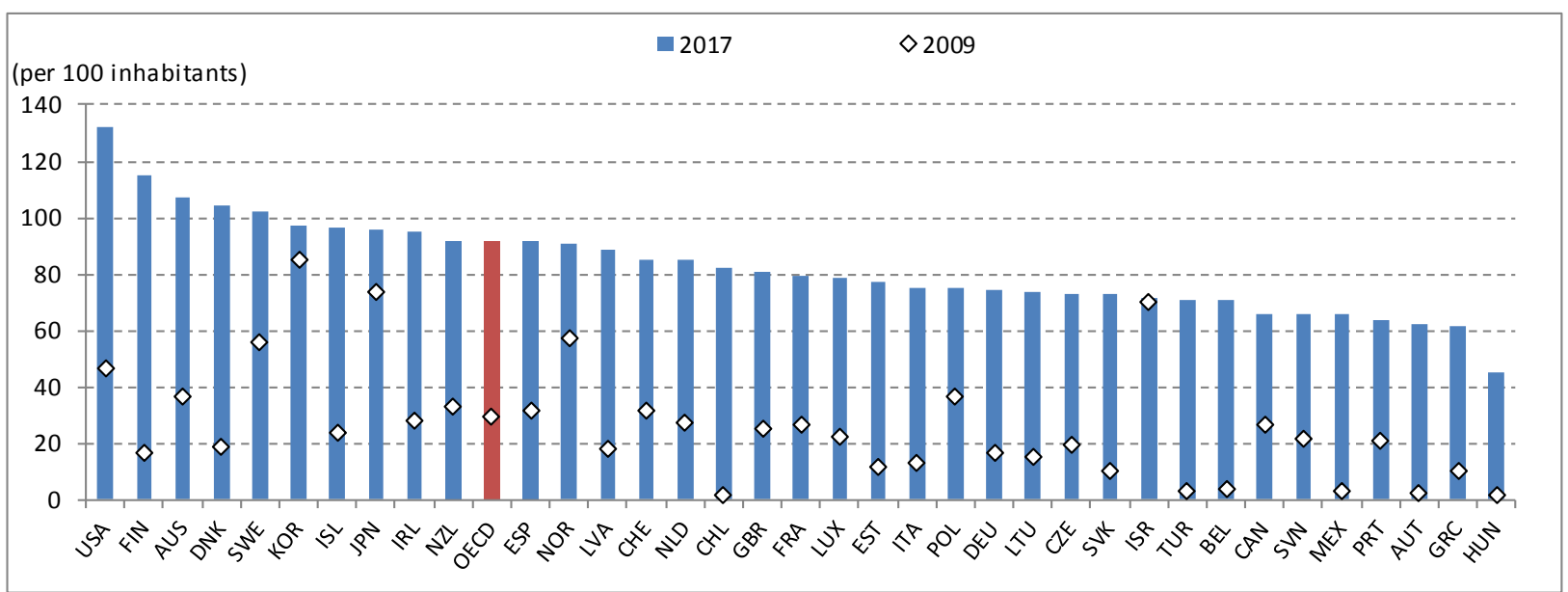

Note: For Australia, Canada, Estonia, Germany, Mexico, the Netherlands, New Zealand and Slovenia, 2010 instead of 2009. For Czech Republic and Lithuania, 2011 instead of 2009.

Source: OECD, Telecommunication Statistics, Broadband database, http://dotstat.oecd.org/Index.aspx?DataSetCode=BROADBAND_DB, January 2019.

The services offered via platforms differ along several dimensions (Figure 2). Services range from the highly capital intensive (such as providing accommodation) to highly labour intensive (such as cleaning) with many services combining capital and labour (such as providing transport) (OECD, 2016 $\left.{ }_{[1]}\right)$. For the purposes of this paper, only those services with a considerable labour content are considered. The nature of the work carried out also varies with tasks that are routine in nature versus non-routine. In addition, tasks can differ between manual tasks that must be delivered physically (such as handyman services or ride hailing) to more cognitive tasks (such as professional services or click 
work) that can be delivered digitally. Such digitally deliverable tasks can potentially be completed either locally or anywhere in the world with a suitable internet connection.

\section{Figure 1.2. There is a wide variety of platform services}

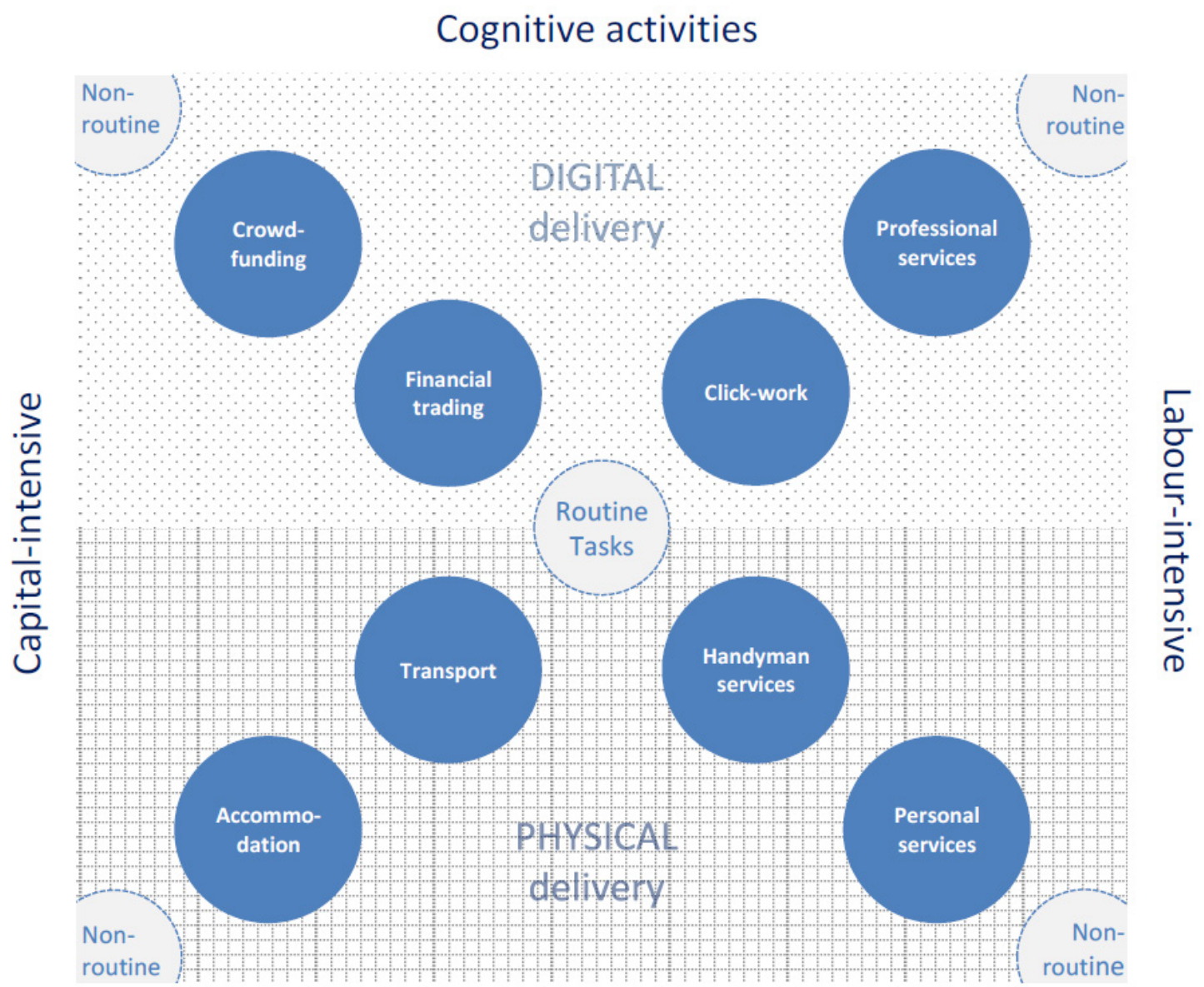

Manual activities

\section{Source: OECD (2016)}

The emergence of online platform work, and the new forms of work that it brings, has the potential to boost employment, increase flexibility for workers, and for some platform workers serve as a transition to regular employment; but has also led to concerns among policy makers (Schwellnus et al., 2019 $\left.{ }_{[8]}\right]$. Platforms facilitate flexible work arrangements, which could lead to an increase in low quality jobs, with poor career prospects, and contribute to a segmented labour market (OECD, 2018 ${ }_{[9]}$; Drahokoupil and Piasna, 2019 $[10]$; Berg et al., 2018 $\left.{ }_{[11]}\right)$. In addition, independent workers are usually not covered by the same labour market protections as standard workers, and may suffer from low wages and poor job quality (Broecke, 2018 ${ }_{[12]}$; OECD, 2018 $8_{[13]}$ ). As the current lack of data hampers the provision of policy advice, there is a need to gather more information regarding platform workers $\left(\mathrm{OECD}, 2018_{[9]}\right.$; Eurofound, 2018 $\left.{ }_{[14]}\right)$. In particular, there is a need for data that is comparable across countries, across time, and with existing labour market statistics. 


\subsection{How the number of platform workers is estimated}

Since the emergence of online platform work, there have been several attempts to estimate the number of workers. Initial attempts made use of existing data sources, combined with strong assumptions, and led to varying estimates of the size of the platform economy (see below). A number of surveys conducted by both researchers and private agencies followed, with government agencies having sponsored some of the research. Although these studies have provided useful insights, the choice of reference period reduces comparability with existing labour market statistics, and they are becoming obsolete due to the introduction of surveys conducted by official statistical agencies of OECD member states. Although such agencies can provide accurate estimates of the total number of platform workers, problems of sample size limit the information they can provide about platform workers' characteristics. The use of big data and administrative sources have the potential to provide such additional information.

\subsubsection{Early estimates of platform workers varied widely}

Some early attempts to estimate the number of platform workers in the US made use of novel data sources. Harris and Krueger $\left(2015_{[15]}\right)$ estimated the number of US platform workers to be $0.4 \%$ of total employment by using data for the number of Uber drivers, and scaling this by the total number of Google searches for a list of 26 labour platforms (relative to the number of Google searches for Uber). The same method was used to estimate that as few as $0.05 \%$ of EU employees were active platform workers at the end of 2015 (Groen and Maselli, 2016 ${ }_{[16]}$ ). Meanwhile, in an update of previous work Farrell et al. $\left(2018_{[17]}\right)$ (see below) used information from the bank accounts of customers to estimate that the number of US based platform workers has risen from approximately $0.4 \%$ of adults in 2015 to approximately $1 \%$ in 2018 .

Since these attempts, researchers have commonly used surveys to estimate the number of platform workers (summarised in Table 1.1), though with wide variation in estimates. Katz and Krueger (2016) aimed to meet the lack of official statistics by conducting a version of the Bureau of Labor Statistics' Contingent Workers Survey (CWS) and found $0.5 \%$ of the workforce perform platform work as their main job. In line with existing labour market statistics, the survey referred to work done in the past week, although they used a different sampling method. In contrast, the PEW Research Centre used a broader definition of platform worker (including those who perform platform work as a secondary job) and a longer reference period (looking at those who performed platform work in previous 12 months) and found that $8 \%$ of US working age adults were platform workers (Pew Research Center, 2016 $[18]$ ). The lower estimates highlight the difficulties in getting information on platform workers due to small sample sizes.

Several attempts have also been made to estimate the number of platform workers in Europe. For the United Kingdom the CIPD (a representative body for British Human Resource professionals) used an online survey to find $4 \%$ of British adults had performed platform work in the past 12 months in 2016 (CIPD, 2017 $\left.7_{[19]}\right)$. However despite using a broader definition (of gigs, including work found using a platform), a slightly lower figure was estimated by the Royal Society for the Encouragement of Arts, Manufactures and Commerce. They estimated 3.1\% of British adults have tried gig work of some form (Balaram, Warden and Wallace-Stephens, 2017 $[20]$ ). Meanwhile, in Germany Bonin and Rinne $\left(2017_{[21]}\right)$ used a telephone survey to estimate that $3.1 \%$ of adults at some point found work via an app. 
Table 1.1. Survey results of non-official agencies

\begin{tabular}{|c|c|c|c|c|c|c|c|c|c|c|c|c|}
\hline Country & $\begin{array}{l}\text { Time the survey } \\
\text { was conducted }\end{array}$ & $\begin{array}{l}\text { Reference } \\
\text { time period }\end{array}$ & $\begin{array}{l}\text { Name of the } \\
\text { survey }\end{array}$ & Concept & $\begin{array}{l}\text { Selection } \\
\text { into sample }\end{array}$ & Sample size & $\begin{array}{l}\text { Survey } \\
\text { method }\end{array}$ & $\begin{array}{c}\text { Platform } \\
\text { work } \\
\text { defined }\end{array}$ & $\begin{array}{c}\text { Example } \\
\text { platform } \\
\text { named }\end{array}$ & $\begin{array}{l}\text { Refers } \\
\text { to } \\
\text { earned } \\
\text { income }\end{array}$ & $\begin{array}{c}\text { Inclusion } \\
\text { of non- } \\
\text { labour } \\
\text { platform } \\
\text { in } \\
\text { estimate }\end{array}$ & $\begin{array}{c}\text { Platform } \\
\text { workers (\%) }\end{array}$ \\
\hline Norway & $\begin{array}{l}\text { September } \\
2016 \text { to } \\
\text { October } 2017\end{array}$ & $\begin{array}{l}\text { In the past } \\
12 \text { months }\end{array}$ & $\begin{array}{l}\text { Alsos et al. } \\
(2017)\end{array}$ & $\begin{array}{l}\text { Platform } \\
\text { workers of } \\
\text { working age on } \\
\text { labour platforms } \\
\text { but also Airbnb }\end{array}$ & $\begin{array}{l}\text { Working } \\
\text { age } \\
\text { population }\end{array}$ & $\begin{array}{l}\text { Survey of } \\
\text { work } \\
\text { providers: } \\
1000 \\
\text { respondents }\end{array}$ & $\begin{array}{l}\text { Pilot surveys } \\
\text { were online, } \\
\text { actual survey } \\
\text { was via } \\
\text { telephone }\end{array}$ & & & & & $\begin{array}{l}0.51 \% \text { of } \\
\text { working age } \\
\text { population }\end{array}$ \\
\hline Great Britan & $\begin{array}{l}\text { November } 11 \text {, } \\
201610^{\text {th }} \\
\text { January, } 2017\end{array}$ & Ever & $\begin{array}{l}\text { Balaram, } \\
\text { Warden and } \\
\frac{\text { Wallace- }}{\text { Stephens }} \\
\underline{(2017)}\end{array}$ & $\begin{array}{l}\text { personally } \\
\text { carried out paid } \\
\text { work using a } \\
\text { website or } \\
\text { mobile phone } \\
\text { application }\end{array}$ & $\begin{array}{l}\text { Residents } \\
\text { aged } 15 \\
\text { and up }\end{array}$ & $\begin{array}{l}7656 \\
\text { respondents }\end{array}$ & Face-to-face & & & Yes & No & $\begin{array}{l}3.17 \% \text { of } \\
\text { respondents } \\
\text { have } \\
\text { previously } \\
\text { carried out gig } \\
\text { work, } 2.17 \% \\
\text { currently do. }\end{array}$ \\
\hline $\begin{array}{l}\text { Italy, the } \\
\text { United } \\
\text { States, and } \\
\text { the United } \\
\text { Kingdom }\end{array}$ & $\begin{array}{l}\text { ITA: May 8- } \\
\text { 15, 2018 } \\
\text { GBR: Feb } 5 \\
\text { and Mar 2, } \\
\text { 2018 } \\
\text { USA: April } \\
\text { 24-27, } 2017\end{array}$ & $\begin{array}{l}\text { Last year? } \\
\text { (Unknown) }\end{array}$ & $\frac{\text { Boeri et al. }}{(2018)}$ & $\begin{array}{l}\text { Jobs organised } \\
\text { via online } \\
\text { platforms }\end{array}$ & $\begin{array}{l}\text { Working } \\
\text { age } \\
\text { population } \\
\text { (the US } \\
\text { survey } \\
\text { sampled } \\
\text { using } \\
\text { online ads } \\
\text { and social } \\
\text { media) }\end{array}$ & $\begin{array}{l}15000 \text { for } \\
\text { Italy and } \\
20000 \text { for } \\
\text { the United } \\
\text { Kingdom, } \\
\text { and } 10368 \\
\text { for the } \\
\text { United } \\
\text { States }\end{array}$ & Online & & & & & $\begin{array}{l}2.6 \% \text { in Italy, } \\
3.0 \% \text { for the } \\
\text { United } \\
\text { Kingdom. No } \\
\text { estimate for } \\
\text { the US }\end{array}$ \\
\hline Germany & & Ever & $\begin{array}{l}\text { Bonin and } \\
\text { Rinne (2017) }\end{array}$ & $\begin{array}{l}\text { Performing paid } \\
\text { work } \\
\text { assignments } \\
\text { obtained via } \\
\text { platforms or } \\
\text { apps }\end{array}$ & & $\begin{array}{l}10000 \\
\text { interviews }\end{array}$ & Telephone & No & No & Yes & No & $\begin{array}{l}3.1 \% \\
\text { currently, an } \\
\text { additional } \\
2.9 \% \text { had } \\
\text { previously }\end{array}$ \\
\hline
\end{tabular}


10 MEASURING PLATFORM MEDIATED WORKERS

\begin{tabular}{|c|c|c|c|c|c|c|c|c|c|c|c|c|}
\hline $\begin{array}{l}\text { United } \\
\text { Kingdom }\end{array}$ & $\begin{array}{l}2^{\text {nd }} \text { to } 15^{\text {th }} \\
\text { December, } \\
2016\end{array}$ & $\begin{array}{l}\text { In the last } \\
12 \text { months }\end{array}$ & CIPD (2017) & $\begin{array}{l}\text { Individuals who } \\
\text { have used an } \\
\text { online platform } \\
\text { at least once to: } \\
\text { 1) provide } \\
\text { transport, } \\
\text { 2) rent their } \\
\text { own vehicle, } \\
\text { 3) deliver food } \\
\text { or goods, } \\
\text { 4) perform } \\
\text { short-term jobs, } \\
\text { or 5) do other } \\
\text { work }\end{array}$ & $\begin{array}{l}\text { A } \\
\text { nationally } \\
\text { representati } \\
\text { ve sample } \\
\text { of UK } \\
\text { adults aged } \\
18 \text { to } 70 .\end{array}$ & $\begin{array}{l}5019 \\
\text { respondents }\end{array}$ & Online & No & Yes & Yes & Yes & $\begin{array}{l}4 \% \text { of adults } \\
\text { in } \\
\text { employment }\end{array}$ \\
\hline $\begin{array}{l}14 \text { EU } \\
\text { countries: } \\
\text { GBR, ESP, } \\
\text { DEU, NLD, } \\
\text { PRT, ITA, } \\
\text { LTU, ROM, } \\
\text { FRA, SWE, } \\
\text { HUN, HRV, } \\
\text { SVK, FIN }\end{array}$ & $\begin{array}{l}\text { Second half of } \\
\text { June, } 2017\end{array}$ & Ever & $\frac{\frac{\text { COLLEEM }}{\text { Pesole et al. }}}{(2018)}$ & $\begin{array}{l}\text { providing } \\
\text { services via } \\
\text { online platforms } \\
\text { where either } \\
\text { 1) both work } \\
\text { and payment is } \\
\text { digital, or } \\
\text { 2) payment is } \\
\text { digital but the } \\
\text { work is } \\
\text { performed on- } \\
\text { location. }\end{array}$ & $\begin{array}{l}\text { Internet } \\
\text { users aged } \\
16 \text { to } 74\end{array}$ & $\begin{array}{l}32389 \\
\text { observations } \\
\text { (approximat } \\
\text { ely } 2300 \\
\text { per country) }\end{array}$ & Online & Yes & Yes & Yes & Yes & $\begin{array}{l}\text { On average } \\
9.7 \% \text { of the } \\
\text { adult } \\
\text { population } \\
\text { have ever } \\
\text { provided } \\
\text { labour to an } \\
\text { online } \\
\text { platform }\end{array}$ \\
\hline $\begin{array}{l}\text { EU-28 } \\
\text { countries }\end{array}$ & March, 2016 & Ever & $\begin{array}{l}\text { Eurobarometer } \\
\underline{(2016)}\end{array}$ & $\begin{array}{l}\text { A collaborative } \\
\text { platform is an } \\
\text { internet based } \\
\text { tool that enables } \\
\text { transactions } \\
\text { between people } \\
\text { providing and } \\
\text { using a service. }\end{array}$ & $\begin{array}{l}\text { Residents } \\
\text { aged } 15 \\
\text { years and } \\
\text { over }\end{array}$ & $\begin{array}{l}\text { Around } 500 \\
\text { interviews } \\
\text { per country }\end{array}$ & $\begin{array}{l}\text { Telephone } \\
\text { interview }\end{array}$ & Yes & No & No & Yes & $\begin{array}{l}32 \% \text { of } \\
\text { respondents } \\
\text { have visited } \\
\text { collaborative } \\
\text { platforms, of } \\
\text { which another } \\
32 \% \text { have } \\
\text { offered } \\
\text { services }\end{array}$ \\
\hline
\end{tabular}


MEASURING PLATFORM MEDIATED WORKERS

\begin{tabular}{|c|c|c|c|c|c|c|c|c|c|c|c|c|}
\hline $\begin{array}{l}\text { United } \\
\text { Kingdom, } \\
\text { Sweden, } \\
\text { Germany, } \\
\text { Austria, and } \\
\text { the } \\
\text { Netherlands }\end{array}$ & $\begin{array}{l}\text { GBR } \\
\text { (January,2016) } \\
\text { SWE } \\
\text { (March,2016) } \\
\text { AUS DEU } \\
\text { NLD } \\
\text { (April,2016) }\end{array}$ & Unknown & $\begin{array}{l}\text { Huws, Spencer } \\
\text { and Joyce } \\
\underline{(2016)}\end{array}$ & $\begin{array}{l}\text { Engaged in paid } \\
\text { work organised } \\
\text { via an online } \\
\text { platform }\end{array}$ & $\begin{array}{l}\text { Respondent } \\
\text { s to Ipsos- } \\
\text { MORI } \\
\text { iOmnibus } \\
\text { online } \\
\text { survey } \\
\text { Working } \\
\text { age } \\
\text { population } \\
\text { (age ranges } \\
\text { between } \\
16-65 \text { and } \\
16-75 \text { ) }\end{array}$ & $\begin{array}{ll}\text { GBR-2 } 238 \\
\text { SWE-2 } 146 \\
\text { AUS-1 } 969 \\
\text { DEU-2 } 180 \\
\text { NLD-2 } 126\end{array}$ & Online & No & & & No & $\begin{array}{l}\text { Between } 9 \text { and } \\
19 \% \text { of } \\
\text { respondents } \\
\text { engaged in } \\
\text { crowd work. }\end{array}$ \\
\hline $\begin{array}{l}\text { United } \\
\text { States, } \\
\text { Germany, } \\
\text { France, } \\
\text { Sweden, } \\
\text { Spain }\end{array}$ & $\begin{array}{l}\text { June and July } \\
2016\end{array}$ & $\begin{array}{l}\text { In the past } \\
12 \text { months }\end{array}$ & $\underline{\text { Manyika et al. }}$ & $\begin{array}{l}\text { Classified } \\
\text { independent } \\
\text { workers } \\
\text { according to a } \\
\text { decision tree. }\end{array}$ & $\begin{array}{l}\text { Working } \\
\text { age } \\
\text { respondents }\end{array}$ & $\begin{array}{l}8131 \\
\text { responses } \\
\text { (minimum } 1 \\
200 \\
\text { responses } \\
\text { per country) }\end{array}$ & $\begin{array}{l}\text { Administered } \\
\text { electronically }\end{array}$ & & & & & $1.5 \%$ \\
\hline $\begin{array}{l}\text { United } \\
\text { States }\end{array}$ & $\begin{array}{l}\text { July } 12 \text { August } \\
8,2016\end{array}$ & $\begin{array}{l}\text { In the past } \\
\text { year }\end{array}$ & $\frac{\text { Pew Research }}{\text { Center }(2016)}$ & $\begin{array}{l}\text { Earned money } \\
\text { by taking jobs } \\
\text { (including } \\
\text { filling surveys) } \\
\text { through a } \\
\text { website that } \\
\text { required a user } \\
\text { profile. }\end{array}$ & $\begin{array}{l}\text { Respondent } \\
\text { s of the } \\
\text { American } \\
\text { Trends } \\
\text { Panel who } \\
\text { self- } \\
\text { identify as } \\
\text { internet } \\
\text { users. }\end{array}$ & $\begin{array}{l}4579 \\
\text { respondents } \\
(4165 \\
\text { online, } 414 \\
\text { via mail) }\end{array}$ & $\begin{array}{l}\text { Online and } \\
\text { via mail }\end{array}$ & Yes & Yes & Yes & No & $\begin{array}{l}8 \% \text { of all } \\
\text { adults } \\
\text { engaged in gig } \\
\text { work. }\end{array}$ \\
\hline Sweden & Autumn, 2016 & $\begin{array}{l}\text { In the past } \\
12 \text { months }\end{array}$ & $\underline{\text { SOU (2017: }}$ & $\begin{array}{l}\text { Attempted to } \\
\text { get a job } \\
\text { through an } \\
\text { online platform }\end{array}$ & Aged 16-64 & $\begin{array}{l}7069 \\
\text { respondents }\end{array}$ & $\begin{array}{l}\text { Web panel, } \\
\text { recruited by } \\
\text { Telephone }\end{array}$ & Yes & Yes & Yes & No & $\begin{array}{l}\text { Around } 4 \% \\
\text { have been } \\
\text { trying, while } \\
\text { around } 2.5 \% \\
\text { of working } \\
\text { age population } \\
\text { has been } \\
\text { successful. }\end{array}$ \\
\hline
\end{tabular}


Meanwhile two Scandinavian surveys highlight the importance of choice of question (see Annex A2). In a telephone survey, Alsos et al., $\left(2017_{[22]}\right)$ found that $0.5 \%$ to $1 \%$ of Norwegian working age adults have used a platform (including capital platforms like AirBnB) to earn income in the past 12 months. They found that questions asked over the phone gave more accurate responses than online surveys, as does mentioning specific platforms. Meanwhile, the importance of specifying whether an individual provided, or merely offered a service is seen in the report for Government of Sweden which found that although $4 \%$ of Swedish working age adults attempted to find work via a platform, only $2.5 \%$ were successful (SOU, 2017 $7_{[23]}$ ).

There have been several cross-country studies of platform workers. McKinsey Global Institute conducted an online survey of 8000 workers across six countries (United States, the United Kingdom, Germany, Sweden, France, and Spain) and found approximately $1.5 \%$ of respondents have earned income via digital labour platforms in the pooled sample (Manyika et al., 2016 $6_{[24]}$ ). In contrast, Huws et al. $\left(2016_{[25]}\right)$ estimated a larger share of platform workers in a survey of seven European countries (sponsored by the Foundation for the European Progressive Studies). They estimate that the number of people who perform platform-work weekly ranges from $4.7 \%$ of the working population in the United Kingdom to $12.4 \%$ in Italy. However, differences in sampling for each country, and the mixture of online and face-to-face surveys, limits cross-country comparability of this study.

In addition, there have been cross-country European studies by Eurobarometer and the European Commission. A Eurobarometer poll estimates the number of adults that provided a service using a platform in 2016 (and updated in 2018), and includes both capital and labour platforms. There is wide variation across countries in the number of platform workers, with as many as $16 \%$ of individuals in France having offered such a service at least once to as low as less than one percent in Malta in 2016, though the French estimate fell to $11 \%$ in 2018 suggesting the understanding of the question changed. The study also highlights the importance of choosing an appropriate reference time horizon as those who regularly supply a service are a small fraction of those who do so occasionally (Eurobarometer, 2016[26]; Eurobarometer, 2018 [27]). 
Figure 1.3. There is wide variation in participation in platform work across countries

Share of individuals having ever offered services on platform in the EU in 2018, by frequency.

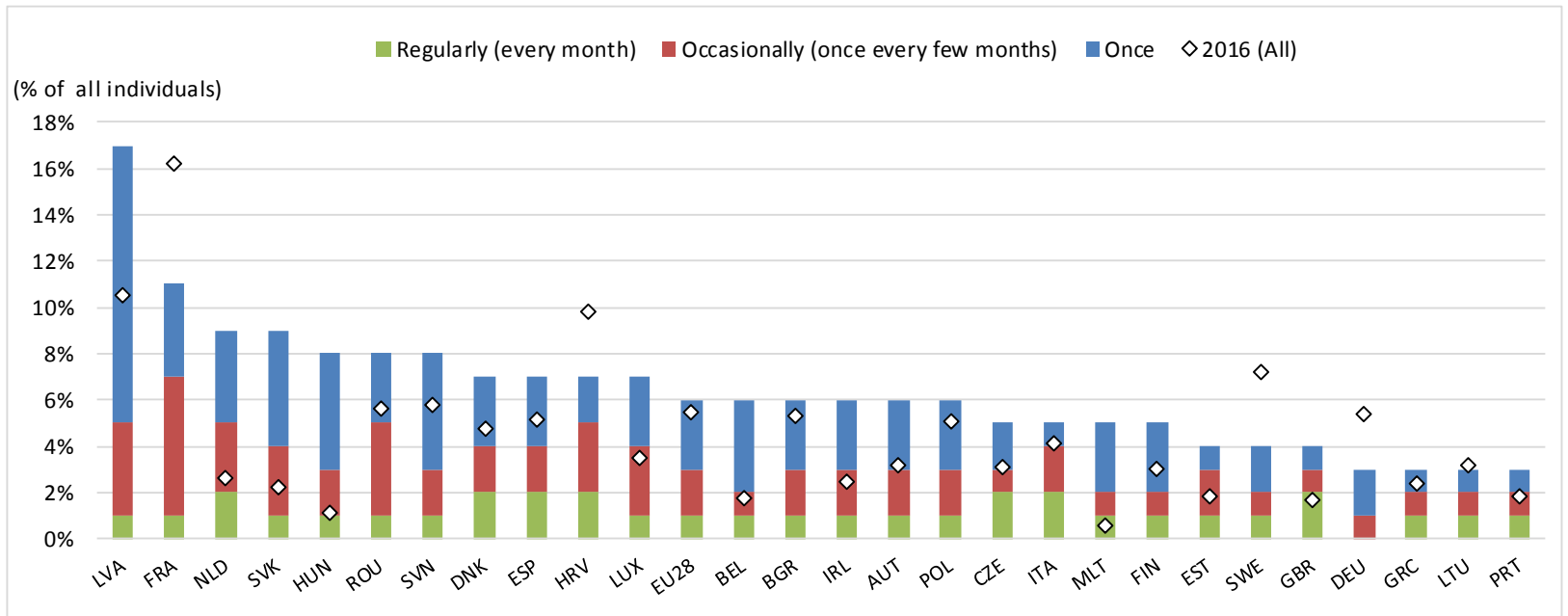

Note: Platforms include capital platforms.

Source: The use of collaborative platforms, Flash Eurobarometer n ${ }^{\circ} 67$, September 2018.

The European Commission's Joint Research Centre carried out a 2017 COLLEEM pilot survey of 14 EU Member States (fielded by the Public Policy and Management Institute). The share of adults engaged in monthly platform work ranges from $4.1 \%$ in Finland to $9.9 \%$ in the United Kingdom. Although the survey was conducted online, the authors considered this appropriate as internet use is a prerequisite for being a platform worker. Potential self-selection bias was corrected for using weights for education, employment status, and frequency of internet use (based on Eurostat's LFS and ICT survey) when reporting results for the adult population as a whole. Nevertheless, bias may remain (Pesole et al., 2018 ${ }_{[28]}$ ). In addition, the effect of differences in concepts and definitions is shown by the lack of correlations with the results of the Eurobarometer survey (Figure 1.4). 
Figure 1.4. Differences in concepts and definitions lead tolittle consistency across estimates

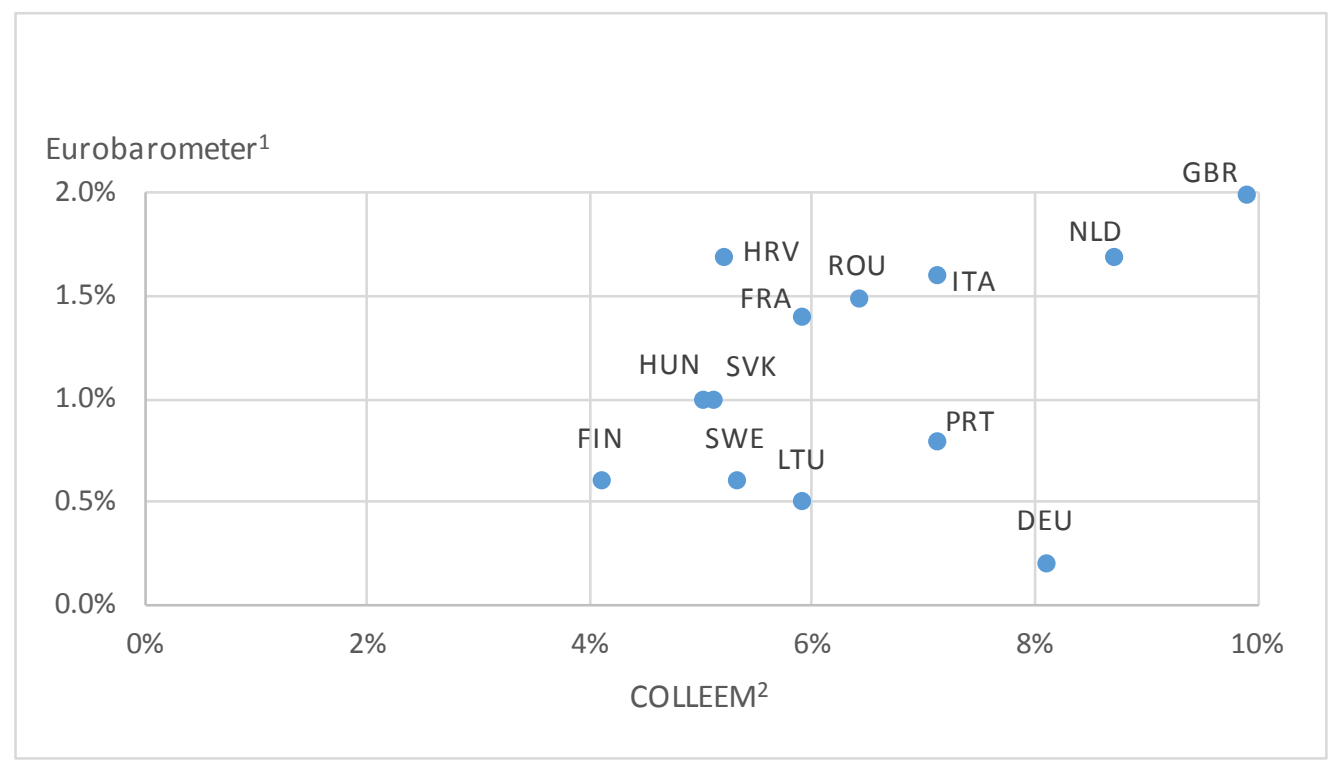

1. Eurobarometer: Percentage of individuals having offered services via collaborative platforms regularly (every month). A collaborative platform is an internet based tool that enables transactions between people providing and using a service. They can be used for a wide range of services, from renting accommodation and car sharing to small household jobs.

2. COLLEEM: Percentage of individuals who provided services via platforms at least once a month during the last year.

Source: OECD, based on data from Eurobarometer (2018) and Pesole et al. (2018).

\subsubsection{There have been some attempts by statistical agencies of OECD Member \\ States}

Existing labour statistics, such as those produced by labour force surveys, have difficulties in tracking platform workers. Such surveys focus on a worker's primary job and can be unreliable in their coverage of secondary jobs and self-employment, and do not capture the greater diversity of employment contracts (Bernhardt and Thomason, 2017 $7_{[29]}$; OECD, 2018 [9]; Abraham et al., 2018[30]). This causes difficulties if platform workers already have a stable job and use platform work to complement their income. Therefore, it is necessary to develop new questions for surveys.

Several official statistical agencies of OECD Member States have conducted pilot surveys to measure the number of consumers and workers using labour platforms (Table 1.2). Initial attempts focused on use of platforms by consumers, and were included in ICT 
Table 1.2. The concept of platform worker used and survey results vary across official surveys

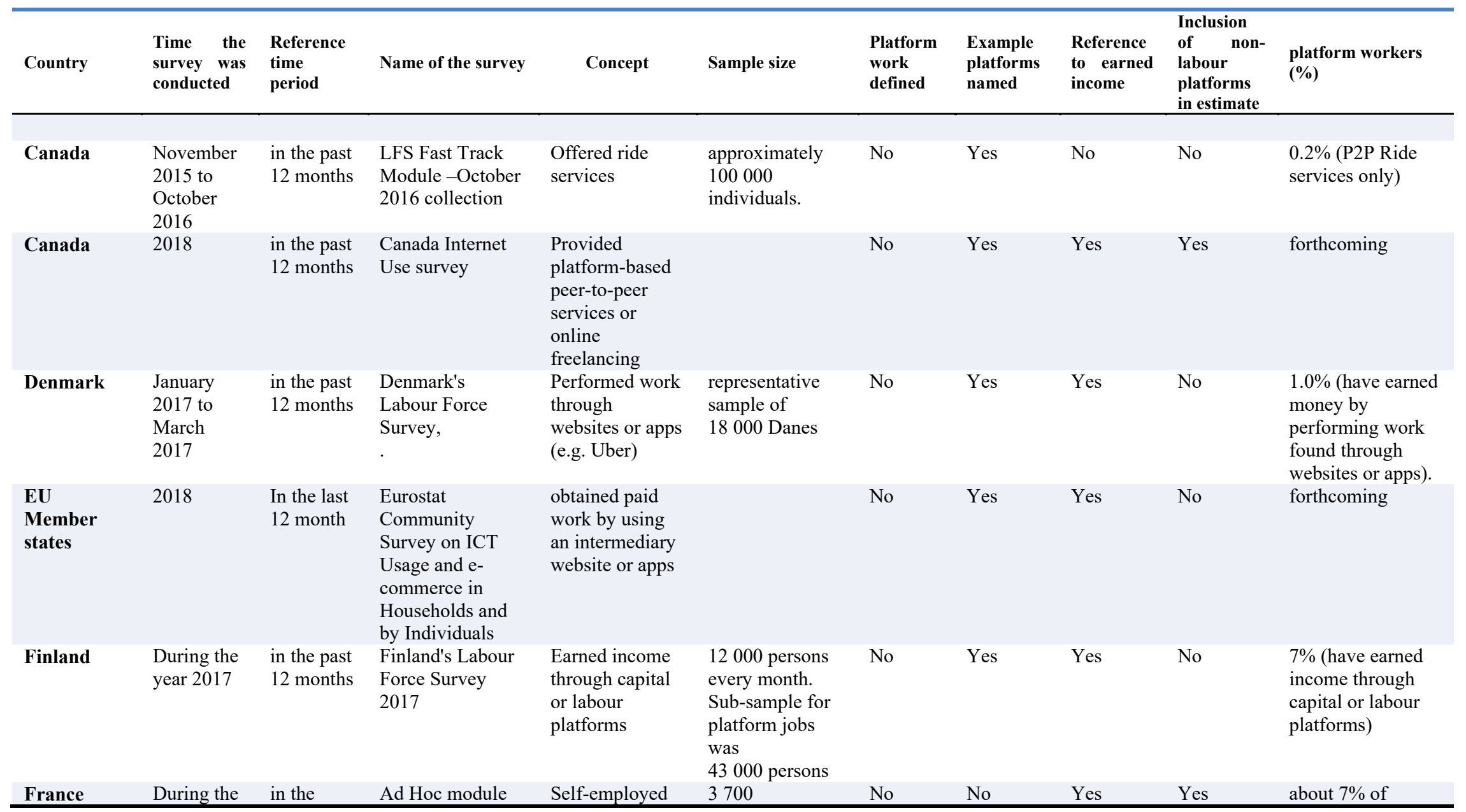

OECD DIGITIAL ECONOMY PAPERS 
16 MEASURING PLATFORM MEDIATED WORKERS

\begin{tabular}{|c|c|c|c|c|c|c|c|c|c|c|}
\hline & year 2017 & $\begin{array}{l}\text { reference } \\
\text { week }\end{array}$ & $\begin{array}{l}\text { of the European } \\
\text { LFS (6th wave } \\
\text { sample) }\end{array}$ & $\begin{array}{l}\text { in main job that } \\
\text { contact clients } \\
\text { through a } \\
\text { platform or a } \\
\text { third party } \\
\text { business }\end{array}$ & $\begin{array}{l}\text { independents } \\
\text { (sample of the } \\
6^{\text {th }} \text { wave of the } \\
\text { LFS "Enquête } \\
\text { Emploi") }\end{array}$ & & & & & $\begin{array}{l}\text { independents and } \\
0.8 \% \text { of the "actifs } \\
\text { occupés" } \\
\text { (employed people) } \\
\text { are using -either } \\
\text { exclusively or not- } \\
\text { a plateform }\end{array}$ \\
\hline Switzerland & 2019 & $\begin{array}{l}\text { In the last } \\
12 \text { months } \\
\text { or last } \\
\text { week }\end{array}$ & Swiss LFS & $\begin{array}{l}\text { Provided taxi or } \\
\text { other services } \\
\text { via an internet } \\
\text { platform or } \\
\text { mobile } \\
\text { application }\end{array}$ & $\mathrm{n} / \mathrm{a}$ & Yes & Yes & Yes & $\mathrm{n} / \mathrm{a}$ & Forthcoming \\
\hline $\begin{array}{l}\text { United } \\
\text { Kingdom }\end{array}$ & & $\begin{array}{l}\text { in the past } \\
12 \text { months }\end{array}$ & $\begin{array}{l}\text { UK ONS } \\
\text { (cognitive/ } \\
\text { qualitative pilot } \\
\text { of questions for } \\
\text { digital platform) }\end{array}$ & $\begin{array}{l}\text { Used an online } \\
\text { platform to find } \\
\text { work }\end{array}$ & $\mathrm{n} / \mathrm{a}$ & No & No & Yes & No & $\mathrm{n} / \mathrm{a}$ \\
\hline $\begin{array}{l}\text { United } \\
\text { States }\end{array}$ & May 2017 & $\begin{array}{l}\text { In the } \\
\text { reference } \\
\text { week }\end{array}$ & $\begin{array}{l}\text { Bureau of Labour } \\
\text { Statistics } \\
\text { Contingent } \\
\text { Worker } \\
\text { Supplement }\end{array}$ & $\begin{array}{l}\text { Use a platform } \\
\text { for digitally or } \\
\text { physically } \\
\text { delivered tasks }\end{array}$ & $\begin{array}{l}60000 \\
\text { households }\end{array}$ & Yes & No & Yes & No & $\begin{array}{l}1 \% \text { following } \\
\text { recoding }(3.3 \% \\
\text { based on survey } \\
\text { responses) }\end{array}$ \\
\hline $\begin{array}{l}\text { United } \\
\text { States }\end{array}$ & $\begin{array}{l}\text { November } \\
2017\end{array}$ & $\begin{array}{l}\text { In the past } \\
6 \text { months }\end{array}$ & $\begin{array}{l}\text { US CPS } \\
\text { Computer and } \\
\text { Internet Use } \\
\text { Supplement }\end{array}$ & $\begin{array}{l}\text { Offered services } \\
\text { via the internet }\end{array}$ & $\begin{array}{l}\text { approximately } \\
106000 \\
\text { persons } 15 \text { years } \\
\text { old and over }\end{array}$ & No & Yes & No & Yes & $\begin{array}{l}6 \% \text { (offering } \\
\text { capital or labour } \\
\text { services for sale } \\
\text { via Internet) }\end{array}$ \\
\hline $\begin{array}{l}\text { United } \\
\text { States }\end{array}$ & $\begin{array}{l}\text { November } \\
\text { and } \\
\text { December } \\
2017\end{array}$ & $\begin{array}{l}\text { In the past } \\
\text { month }\end{array}$ & $\begin{array}{l}\text { FED Report on } \\
\text { the Economic } \\
\text { Well-Being of } \\
\text { U.S. Households } \\
\text { in 2017. Survey } \\
\text { of Households } \\
\text { Economics and } \\
\text { Decision-making } \\
\text { (SHED) }\end{array}$ & $\begin{array}{l}\text { Secondary } \\
\text { income from } \\
\text { online tasks or } \\
\text { ride sharing }\end{array}$ & $\begin{array}{l}12246 \text { panel } \\
\text { members }\end{array}$ & No & Yes & Yes & No & $\begin{array}{l}4 \% \text { (paid for } \\
\text { completing online } \\
\text { tasks) / } 2 \% \\
\text { (driving using a } \\
\text { ride-sharing app) }\end{array}$ \\
\hline
\end{tabular}


usage surveys (such as those of Eurostat). However, now questions asking whether participants engage in platform work are being included in internet use surveys in Canada, the United States, and with an EU-wide survey planned for early 2018. More recently, questions have been included in labour force surveys (LFSs) in Canada, the United States, Denmark, and Finland. However, while the available results given are not comparable across countries, they show a variety of approaches to dealing with the issues of providing definitions to questionnaire respondents, and setting appropriate reference periods.

Estimates of the number of platform workers range from $6 \%$ in the US Computer and Internet Use Supplement to under 1\% in France (Table 1.2, above). In addition to cross country differences, there is also substantial variation with surveys done by private agencies (see above). Some of the differences in estimated platform use are due to differences between countries and over time. However, results from the US Computer and Internet Use Supplement (CIUS) (which is commissioned by the US National Telecommunications and Information Administration) and the Bureau of Labor Statistic's US Contingent Worker Supplement (CWS) (both of which are compiled as supplements to the Current Population Survey) show that a broader definition can greatly increase the estimated number of platform workers. The estimates also show that a small number of platform workers are likely to be included in each sample, making it difficult to gain descriptive statistics of platform workers via official surveys.

\section{Different approaches have been taken to help respondents understand platform work}

When asking whether a person is a platform worker it is necessary that respondents have an understanding of platform workers that is robust to changes in legal rulings and the entry or exit of new platforms. Only the United Kingdom's ONS have explicitly referred to finding work on a 'digital platform' in a pilot survey, but many respondents poorly understood the term. Other statistical agencies have taken the approach of providing a definition of platform workers, giving examples of platforms, or to restricting the question to a narrower range of platforms, such as ride-hailing (Annex A1). In addition, the ordering of questions, and use of probing questions, can affect the outcome of surveys (Abraham and Amaya, 2018[31]).

The only statistical agency to include a detailed description of platform work is the US Bureau of Labor Statistics (in the 2017 CWS). While a detailed description is appropriate for an occasional survey focusing specifically on contingent workers, it is likely to be cumbersome if included in a regular survey, such as quarterly labour force surveys.

Although the CWS does not explicitly mention platforms, the question refers to finding work (performed in-person) 'through companies that connect [workers] directly with customers using a website or mobile app'. Therefore, the description is robust to whether or not the worker considers themselves to be self-employed or an employee of the platform. In addition, the description states that the app or website coordinates payment for the service. The description aims to reduce the possibility respondents including capital intensive services (such as providing accommodation) by referring to short 'tasks or jobs', although respondents may differ in their understanding of what is considered a short duration of time, and may exclude freelancing. Finally, the description gives the example of providing transport or household chores, but does not refer to specific platforms. A similar level of detail is given for platform work delivered online. 
However, many respondents poorly understood the definition, such as answering yes if they merely made use of a computer or mobile app in their job. After recoding the data (such as by remobing obviously incorrect responses including hairstylisits that said they did their work entirely online), the estimated number of platform workers was reduced from 3.3\% to 1\% (Bureau of Labor Statistics, 2018 [32]).

Far shorter questions have been included in other surveys, such as the Labour Force Survey of Denmark, though it is questionable as to whether they convey to respondents a clear understanding of platform work. The Danish survey asks whether respondents earned money by 'performing work done through websites or apps'. While this captures the integral role of platforms in interacting with customers, it is not limited to peer-topeer connections, and is thus broader in scope (Ilsøe and Madsen, 2017 ${ }_{[33]}$ ). Eurostat attempted to overcome this problem in the 2018 Eurostat ICT Usage in Households and by Individuals Survey by referring to intermediary websites or apps. However, it is questionable as to whether all respondents would have the same understanding of the term intermediary. Although Eurostat does not say the work must be performed through the app or website, they do explicitly exclude employment agencies. However, robustness checks (such as asking participants to name the platform which they work with) have shown respondents poorly understood the question, and as a result Eurostat chose not to publish the results.

Several surveys offer clarity by asking separate questions for capital and labour platforms. The Canadian Internet Use Survey offers six categories of platforms (including capital platforms and platforms for the sale of goods) from which respondents can choose. The US Federal Reserve's Survey of Households Economics and Decisionmaking (SHED) similarly offers four categories, although ride sharing is the only physically delivered platform work included. While there is an 'Other online paid activities' category it is ambiguous as to whether a respondent would include physically delivered services, such as handiwork, in this category. The Danish LFS asks a separate question for those who earned money 'performing work' and those who rented property, while the Canadian LFS refers specifically to ride services and private accommodation services (to the exclusion of all other platforms). However, the United States CIUS Supplement and Statistics Finland do not distinguish between work and capital platforms. Adding extra categories of capital platforms is superfluous where the intention is to measure platform workers, and using a phrase such as 'performing work' is likely to be sufficient to eliminate capital platforms from responses. However, it may be desirable to distinguish between online and physically delivered platform work.

Most official surveys give respondents named examples of online platforms to aid understanding of work platforms; however, this may reduce comparability over time if the popularity of example platforms wanes. The most commonly given example is that of Uber, named in five surveys. The Finnish question also refers to Uber, but in addition some platforms specific to Finland (such as Tori.fi) are also given (Statistics Finland, $2018_{[34]}$ ). While making use of national specific platforms can help understanding, it may also have the potential to reduce cross-country comparability. Of the surveys that do not offer an example, the French LFS combines both platforms and businesses that direct customers to the worker (and so a more nuanced understanding of platforms is not required) while the US Bureau of Labor Statistics offer a detailed description (Insee, $\left.2018_{[35]}\right)$. 


\section{Cross-country comparability will require consistent phraseology}

There are also number of relatively minor differences in phraseology between surveys; experience from Sweden's State Public Reports (SOU) suggests that this can have a large effect on the estimated number of platform workers (SOU, 2017 $\left.{ }_{[23]}\right)$. These include asking if the respondent offered, or provided, a service; whether the question is broad enough to include those who perform occasional platform work for secondary income; and the chosen reference period.

Almost all surveys ask whether the worker provided a service, implying the worker completed a commercial transaction. However, the US CIUS asks whether a service was offered for sale (rather than provided); leaving it ambiguous as to whether a transaction was completed. In addition, the Canadian LFS asks whether the respondent offered a service (and not necessarily provided) and does not mention the earning of income, meaning the survey could include those who offered a service for charitable reasons, and did not complete a commercial transaction.

Labour force employment statistics have traditionally focused on a worker's main occupation. However, platform work offers workers the flexibility to earn additional income. Only the French LFS excludes those who perform platform work as a secondary job (by means of a series of filter questions). In contrast the US Fed only include secondary income, while the US Bureau of Labour Statistics, 2018 Canadian Internet Use Survey, and 2018 Eurostat ICT Usage Survey asks the respondent to specify whether the work done was as a workers main job, or for secondary income.

A related problem in comparing estimates of the number of platform workers with other categories of employment is the reference time-period for when the respondent performed platform work. Labour force surveys typically ask for a respondents employment status in the past reference week. However, only the Bureau of Labor Statistics (CWS) asks whether the respondent performed platform work in the last week. In contrast, surveys such as the Canadian, Danish, and Finnish LFS refer to the past 12 months. As can be seen in Figure 1.3 (above) the use of a longer reference period can greatly increase the estimated number of platform workers. Using a longer reference period also increases the share of occasional platform workers in the estimated number of platform workers. Therefore, asking whether a respondent performed platform work in the past 12 months as filter question, and then whether they performed platform work in the past week can ensure comparability, and also capture the larger number of irregular platform workers. However, it can also be argued that the number of hours dedicated to platform work is more relevant than then frequency someone works on a platform (Pesole et al., 2018 [28]). 


\subsection{Alternative data sources can give a richer understanding of platform workers}

Although the surveys of official statistical agencies are likely to be the best way to estimate the total number of platform workers, the relatively small overall number of platform workers means that sample sizes are too small to give statistically significant information on the characteristics of platform workers. In addition, such surveys cannot provide information on past trends in the number of platform workers. However, alternative data sources, such as administrative data or data provided by platforms may complement the information gained from official surveys.

\subsubsection{There is a lack of administrative data regarding platform workers}

Administrative data can overcome the problem of small sample size, and reduces the burden on data providers and reduces the cost of data collection. However, administrative data was not collected for statistical purposes, and may have problems of timeliness, relevance, and accuracy (Office for National Statistics, 2016 ${ }_{[36]}$ ). Administrative data has offered insights into contingent workers (such as employees who occasionally perform secondary work to earn additional income); though so far this has been of limited benefit to investigating platform workers. For example, Jackson et al. (2017 [37]) used US tax returns to gain insights into non-standard workers, but were unable to disaggregate online platform workers.

Administrative data has shortcomings that particularly affect the measurement of platform workers. As workers may engage in platform work as a secondary job, administrative datasets may not capture them. For example, the United Kingdom's InterDepartmental Business Register is uses as a sampling frame for ONS business surveys, but it does not include very small firms below the VAT threshold (Office for National Statistics, 2016 $\left.6_{[36]}\right)$. In addition, due to ambiguities in the regulation of digital work platforms, they may be omitted from some datasets. For example, ride hailing apps blur the lines between on street hailing of a cab, and pre-booking a chauffeur and many apps take advantage of loop-holes in existing labour market regulation (Broecke, 2018 ${ }_{[12]}$ ). The tendency of online platforms to locate in such blurred regulatory boundaries creates obstacles to the use of administrative data. Finally, as systems of administration differ across countries, comparability is limited.

Despite these difficulties, Abraham et al. (2018[38]) made use of Canadian administrative data in the taxi and limousine sector, combined with data on when ridesharing platforms became available in a city, to identify the characteristics of new entrants to the sector since platforms were introduced. Such entrants are more likely female, younger, and white than incumbent drivers and more likely to have employee income from other jobs. However, this methodology is likely to become less useful over time, as online platforms become more prevalent, making identification of their effect harder.

Partnerships with online platforms to improved tax collection have the potential to improve administrative data sources. For example, the Estonian Tax and Customs Board (ETCB) has reached an agreement with two ride-sharing platforms to share their data with the (ETCB). However, drivers must first give consent to share their data, which can lead to selection bias. The Mexican Tax Administration (SAT) has reached an agreement whereby drivers must be officially certified before registering with a platform (OECD, $2018_{[39]}$ ). Meanwhile in France, from 2019 online platforms are obliged to report the annual gross income an individual earns on the platform to the tax authorities and in 
Belgium platforms are obliged to both withhold taxes, and report information to the tax authorities (HM Revenue and Customs, 2018 [40]; European Commission, 2017 $[41]$ ).

\subsubsection{Private data sources can give additional insights}

The use of some alternative large datasets can also provide useful insights into the characteristics of platform workers. Using data from the bank accounts of those who received payments from online platforms, economists at JP Morgan Chase were able to investigate the characteristics of platform workers using data on 39 million Chase checking accounts (Farrell and Greig, 2016 ${ }_{[42]}$; Farrell, Greig and Hamoudi, 2018 ${ }_{[17]}$ ). In line with other studies they found that approximately $1 \%$ of workers (double that of early 2016) used an online platform, earning an average of under USD 800 per month, with the earnings of those using transportation apps having fallen by half since 2013. There is also a high rate of workers entering and leaving the sector. Such high churn highlight the need for an appropriate reference period when comparing the numbers of platform workers with other employment sectors.

The use of web-scraping can also be used to see trends in parts of the platform labour market. The Online Labour Index (OLI) measures the utilisation of online labour platforms over time across countries and occupations, and although it does not give an estimate of the absolute number of online workers it does capture trends. The index is based on tracking all projects and tasks posted on a sample of platforms, using an application-programming interface (API) and web-scrapping. The index is limited to platforms through which buyers and sellers of labour or services transact fully digitally: the worker and employer are matched digitally, the payment is conducted digitally via the platform, and the result of the work is delivered digitally. The samples include the top five platforms for which it was possible to collect data over time and which accounted for at least $70 \%$ of all traffic to online labour platforms (according to Alexa's figures) (Kässi and Lehdonvirta, 2018 $\left.{ }_{[43]}\right)$. The current sample is limited to English-language platforms.

The OLI suggests that the number of people engaged in purely online platform work appears to be stabilising (Figure 1.5). Given the relatively short length of the time series, it is difficult to assess whether trends are due to seasonal variation or long-term factors, though this shortcoming will be eliminated with time. In addition the majority of such workers are located in South Asia, and only about a fifth within OECD member states (Kässi and Lehdonvirta, 2018[43]). 
Figure 1.5. New vacancies listed on the top 5 English-language online working platforms

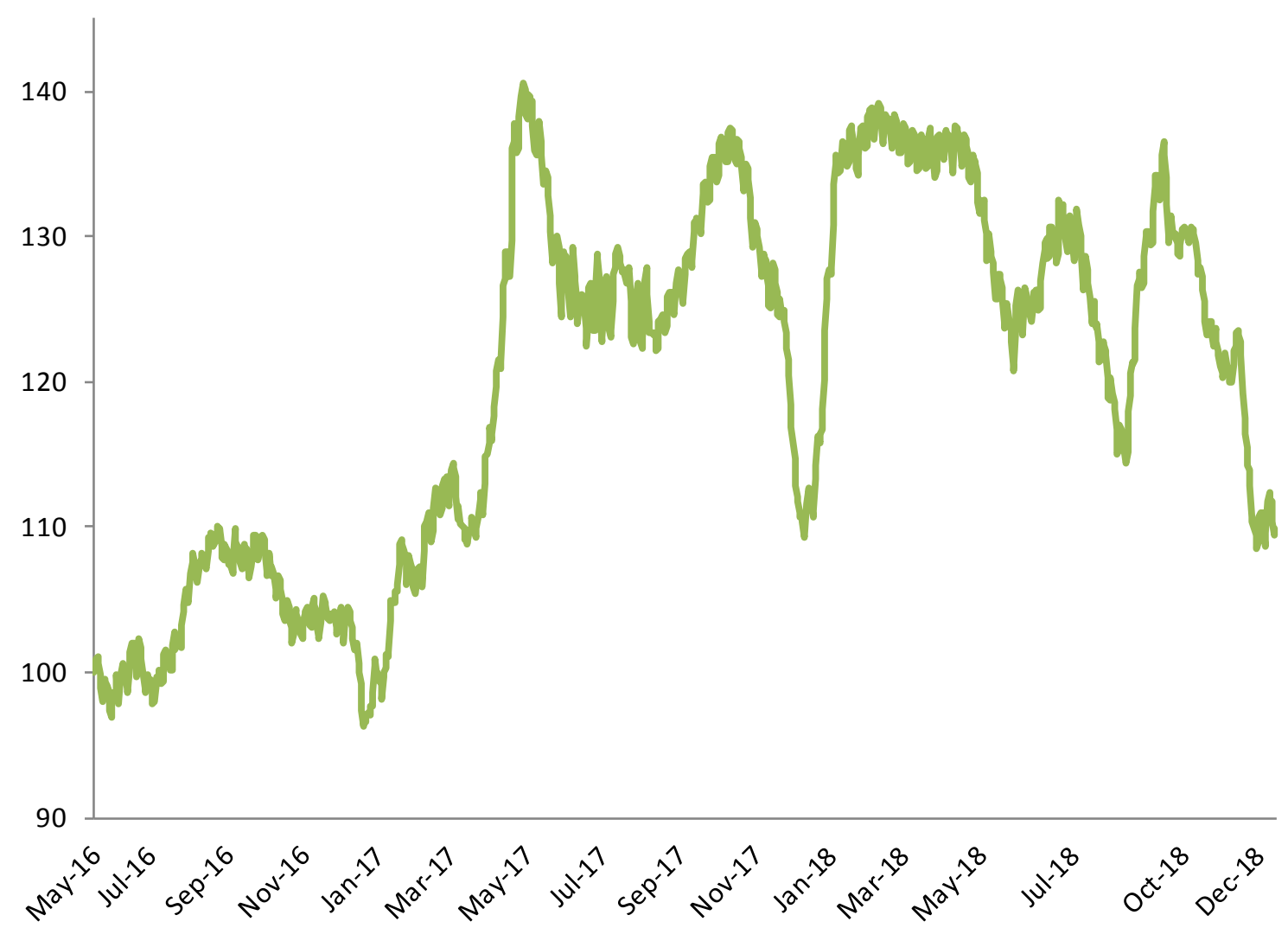

Note: This Figure was generated with data from the Online Labour Index (OLI), which crawls the largest English-language online labour platforms daily: Freelancer, Guru, Mechanical Turk, PeoplePerHour, and Upwork.

Source: OECD and the Online Labour Index, http://ilabour.oii.ox.ac.uk/online-labour-index/.

However, it should be noted that data provided by platforms can have similar problems to administrative data (as the number of registered users could be more than the number of actual users) (Office for National Statistics, 2016 [36]). Therefore, such data can complement rather than replace surveys.

\subsubsection{Data from platforms can also give insights into general labour market problems}

The rich data on wages and hours worked by platforms can also serve as a resource to look at issues general to the labour market, rather than estimating the size of the platform workforce. This is highlighted by the study of (Cook et al., 2018[44]) who used data on over a million drivers to examine the gender wage-gap and decomposed its components, such as women being less willing to work anti-social hours (perhaps due to home duties or a lack of safety in working late at night).

\subsection{How to measure platform workers in the future}

To date several methods have been used to measure the number of platform workers, although differences in definitions and methodologies limit their comparability. There are 
several possible methodologies for measuring platform workers and their characteristics, and those of their job or tasks, each with different advantages and disadvantages. For surveys, a key problem is how to ensure respondents understand the meaning of platform work. The appropriate method depends on the research objectives, the resources available, and the trade-offs faced by researchers or statistical agencies.

If the objective is to ensure consistency with existing labour force statistics it is necessary to include a question on platform workers in the labour force surveys of official statistical agencies. This ensures that identical sampling frames are used. In addition, using the same reference week (rather than a longer time horizon) as the labour force survey is also necessary. This is likely, however, to give a low overall estimate, as those who only perform gig work occasionally are less likely to be captured.

To gain consistent statistics over time it is necessary that respondents to questionnaires have a similar understanding of the question in each period. Although giving named examples of platforms to respondents is likely to be an easy way to convey the meaning of platform work, this can be problematic as different platforms enter or exit the market. The use of some existing big-data sources, such as used by Farrell et al. $\left(2018_{[17]}\right)$, can allow researchers to retrospectively refine their research question as new platforms enter the market, however methodologies which rely on web-scraping may have problems of consistency over-time as platforms are added, or dropped, from the list of platforms that are monitored.

For researchers wishing to ensure cross-country comparability, the use of named platforms in survey questions may again be problematic. This is as not all platforms may operate in each country, or be equally well known. In addition, the potential use of administrative data is likely to be very limited due to differences in administrative systems across countries. Therefore, the use of surveys is likely to be the best approach to gaining cross-country statistics.

For researchers that are only interested in the use of a platform by a specific category of worker (such as the self-employed) it can be possible to start with filter questions to identify the target group, and then phrase the question specific to that group (such as by asking the self-employed how they interact with customers). However, this is at the expense of limiting comparability of the data gained with other surveys.

In addition, the choice of reference period will affect they type of workers captured in a survey. For researchers mainly interested in those who regularly perform platform work, asking whether someone performed such work in the reference week is appropriate. However, for those also wishing to capture occasional platform work a longer time horizon is needed. Therefore asking an additional question as to whether someone performed platform work in the last 12 months may be appropriate, and would allow greater consistency with previous surveys. In addition, careful consideration should be given to the ordering and filtering of questions to ensure that it is clear about which episode of platform work respondents are referring to if answering subsequent questions about the nature of the work or tasks they performed.

The overall importance of the topic of platform workers to a survey affects the appropriate amount of space devoted to formulating an easily understandable question. However, rather than give a detailed definition of platform workers (as was done by the Bureau of Labor Statistics) a series of short questions can be asked concerning different elements of the definition of platform worker, and the interviewer can then determine whether or not the respondent is a platform worker. Filter questions can also be used to 
determine the nature of the work conducted, such as whether the service was provided online or delivered physically. This approach also has the advantage of ensuring the survey is robust to changes in traditional employment, such as firms using apps to roster workers' hours.

Although labour force surveys are the best option for those wishing to learn of labour market questions (and to get a sense of the overall prevalence of platform work), ICT usage surveys can be a better option for those concerned with the use of technology. The appropriate phraseology of the question may also differ, as researchers may be interested in those who used a technology to offer a service, and not just on those who physically provided a service. Time use surveys have the advantage of being able to capture platform work done for short period, but have the disadvantage of not being frequently conducted. Finally, income surveys are appropriate to examine whether individuals earn a significant portion of their income from platform work.

Finally, while the use of official surveys such as labour force surveys is likely to give accurate, and robust, estimates, problems of sample size reduces their suitability for gaining insights into the characteristics of platform workers. Even though the sample size of labour force surveys are typically very large, they will nevertheless lack statistical precision about specific characteristics of very small groups in the population such as platform workers. Therefore, use of other sources (such as administrative datasets or big data) may be necessary. At present, the possibilities of using administrative data are limited, but they may increase as tax authorities develop data-sharing agreements with platforms. In addition, the use of online surveys can reduce costs (though possibly at the expense of reduced accuracy), allowing researchers to reach out to a larger number of respondents. Such approaches can be complementary to the use of official surveys, which can be used to test the overall accuracy of other approaches and to calibrate their results.

Potential next steps could include the formulation of questions to be included in a labour force survey or ICT usage survey to estimate the number of platform workers. It is also necessary to decide upon the appropriate survey for different topics: for example a survey may be appropriate for questions regarding the service provided (such as whether services are delivered physically or online), but inappropriate for questions regarding hours worked or whether platform work is a person's primary or secondary job. Finally, more experimentation in terms of ordering of questions and use of prompting questions may be necessary before such questions are included in surveys. 


\section{References}

Abraham, K. and A. Amaya (2018), "Probing for Informal Work Activity”, NBER Working Paper 24880.

Abraham, K. et al. (2018), Driving the Gig Economy.

Abraham, K. et al. (2018), "Measuring the Gig Economy: Current Knowledge and Open Issues", NBER Working Paper 24950.

Alsos, K. et al. (2017), “Når sjefen er en app”, Fafo-rapport, Vol. 2017/41.

Balaram, B., J. Warden and F. Wallace-Stephens (2017), "Good Gigs: A fairer future for the UK's gig economy".

Berg, J. et al. (2018), Digital labour platforms and the future of work: Towards decent work in the online world, ILO.

Bernhardt, A. and S. Thomason (2017), What Do We Know About Gig Work in California? An Analysis of Independent Contracting.

Bonin, H. and U. Rinne (2017), "Omnibusbefragung zur Verbesserung der Datenlage neuer Beschäftigungsformen”, IZA Research Report 80, http://ftp.iza.org/report pdfs/iza report 80.pdf.

Broecke, S. (2018), Protecting workers from low pay in the future world of work: Are piece rate minimum wages part of the answer.

Bureau of Labor Statistics (2018), "Electronically mediated work: new questions in the Contingent Worker Supplement”, Monthly Labor Review, https://www.bls.gov/opub/mlr/2018/article/electronically-mediated-work-new-questions-inthe-contingent-worker-supplement.htm (accessed on 2018).

CIPD (2017), To gig or not to gig? Stories from the modern economy.

Cook, C. et al. (2018), The Gender Earnings Gap in the Gig Economy: Evidence from over a Million Rideshare Drivers.

Dølvik, J. and K. Jesnes (2017), Nordic labour markets and the sharing economy: Report from a pilot project, TemaNord, Nordic Council of Ministers, Copenhagen K, http://dx.doi.org/10.6027/TN2017-508. 
Drahokoupil, J. and A. Piasna (2019), "Work in the platform economy: Deliveroo riders in Belgium and the SMart arrangement", ETUI Working Paper, Vol. 2019/1.

Eurobarometer (2018), “The use of the collaborative economy”, Flash Eurobarometer 467.

Eurobarometer (2016), "The use of Collaborative Platforms", Flash Eurobarometer 438, http://ec.europa.eu/COMMFrontOffice/publicopinion/index.cfm/ResultDoc/download/Docum entKy/72885.

Eurofound (2018), Employment and working conditions of selected types of platform work, Publications Office of the European Union.

European Commission (2017), Europe's Digital Progress Report (EDPR) 2017 Country Profile Belgium.

Farrell, D. and F. Greig (2016), Paychecks, Paydays, and the Online Platform Economy - Big Data on Income Volatility.

Farrell, D., F. Greig and A. Hamoudi (2018), The Online Platform Economy in 2018: Drivers, Workers, Sellers, and Lessors.

Groen, W. and I. Maselli (2016), "The Impact of the Collaborative Economy on the Labour Market", CEPS Special Report 138.

Harris, S. and A. Krueger (2015), “A Proposal for Modernizing Labor Laws for Twenty-FirstCentury Work: The "Independent Worker"”, Hamilton Project Discussion Paper, Vol. 2015/10.

HM Revenue and Customs (2018), The role of online platforms in ensuring tax compliance by their users.

Hunter, D. and K. Leslie (2018), Statistical definition and measurement of dependent "selfemployed" workers: Rationale for a statistical category of dependent contractors, International Labour Organisation, https://www.ilo.org/wcmsp5/groups/public/---dgreports/--stat/documents/meetingdocument/wcms 636042.pdf.

Huws, U., N. Spencer and S. Joyce (2016), Crowd Work in Europe: Preliminary resultsfrom a survey in the UK, Sweden, Germany, Austria and the Netherlands.

Huws, U., N. Spencer and D. Syrdal (2018), "Online, on call: the spread of digitally organised just-in-time working and its implications for standard employment models", New Technology, Work and Employment, Vol. 33/2, pp. 113-129, http://dx.doi.org/10.1111/ntwe.12111.

Ilsøe, A. and L. Madsen (2017), "Digital af arbejdsmark: Danskernes erfaring med digital automatisering og digitale [Digitalization of the labour market - digital automation and digital platforms in Denmark]", FAOS Forskningsnotat 157.

Insee (2018), Emploi, chômage, revenus du travail, Insee, https://www.insee.fr/fr/statistiques/fichier/3573876/ecrt18.pdf. 
Jackson, E., A. Looney and S. Ramnath (2017), “The Rise of Alternative Work Arrangements: Evidence and Implications for Tax Filing and Benefit Coverage", Office of Tax Analysis Working Paper 114.

Kassi, O. and V. Lehdonvirta (2016), Online Labour Index: Measuring the Online Gig Economy for Policy and Research.

Kässi, O. and V. Lehdonvirta (2018), "Online Labour Index: Measuring the Online Gig Economy for Policy and Research", Technological Forecasting and Social Change .

Katz, L. and A. Krueger (2016), The Rise and Nature of Alternative Work Arrangements in the United States, 1995-2015, National Bureau of Economic Research, Cambridge, MA, http://dx.doi.org/10.3386/w22667.

Manyika, J. et al. (2016), Independent work: Choice, necessity, and the gig economy, https://www.mckinsey.com/ /media/McKinsey/Featured\%20Insights/Employment\%20and\% 20Growth/Independent $\% 20$ work $\% 20$ Choice $\% 20$ necessity $\% 20$ and $\% 20$ the $\% 20$ gig $\% 20$ econo my/Independent-Work-Choice-necessity-and-the-gig-economy-Full-report.ashx.

OECD (2019), Online Platforms: A Practical Approach to their Economic and Social Impacts.

OECD (2019), "Policy responses to new forms of work", forthcoming.

OECD (2018), "Diversity in employment contracts, very atypical employment, and worker classification", forthcoming.

OECD (2018), Measuring Platform and other new forms of work.

OECD (2018), Tax Challenges Arising from Digitalisation - Interim Report 2018: Inclusive Framework on BEPS, OECD/G20 Base Erosion and Profit Shifting Project, OECD Publishing, Paris, http://dx.doi.org/10.1787/9789264293083-en.

OECD (2018), The Future of Social Protection: What Works for Non-standard Workers?, OECD Publishing, Paris, https://dx.doi.org/10.1787/9789264306943-en.

OECD (2016), "New Forms of Work in the Digital Economy", OECD Digital Economy Papers, No. 260, OECD Publishing, Paris, http://dx.doi.org/10.1787/5jlwnklt820x-en.

Office for National Statistics (2016), The feasibility of measuring the sharing.

Office of National Statistics (2017), The feasibility of measuring the sharing economy: November 2017 progress update.

Pesole, A. et al. (2018), Platform Workers in Europe, Publications Office of the European Union.

Pew Research Center (2016), Gig Work, Online Selling and Home Sharing.

Schwellnus, C. et al. (2019), "Gig economy platforms - Boon or bane?", Economics Department Working Paper forthcoming. 
SOU (2017), Ett arbetsliv i förändring - hur påverkas ansvaret för arbetsmiljön?.

Statistics Finland (2018), Labour Force Survey 2017: Platform Jobs, http://www.stat.fi/til/tyti/2017/14/tyti $2017 \quad 14 \quad 2018-04-17$ en.pdf. 


\section{Annex 1.A. Questions Posed in Surveys}

Annex Table 1.A.1. Questions posed in surveys of private agencies

\begin{tabular}{|c|c|}
\hline Survey & $\begin{array}{l}\text { Questions (or selection } \\
\text { method) }\end{array}$ \\
\hline \multirow[t]{7}{*}{ Alsos et al. (2017) } & $\begin{array}{l}\text { Pilot Question: } \\
\text { Recently, there has been a lot of } \\
\text { attention around companies that use } \\
\text { apps and websites to convey work and } \\
\text { services. This is usually called the } \\
\text { sharing economy. }\end{array}$ \\
\hline & $\begin{array}{l}\text { Below are a list of such companies. } \\
\text { Have you done any assignments or } \\
\text { paid employment through one or more } \\
\text { of the following companies in the last } \\
12 \text { months? }\end{array}$ \\
\hline & $\begin{array}{l}\text { 1. Uber } \\
\text { 2. Foodora } \\
\text { 3. weClean } \\
\text { 4. Upwork } \\
\text { 5. Konsus } \\
\text { 6. Haxi } \\
\text { 7. FINN småjobber } \\
\text { 8. Other } \\
\text { 9. No }\end{array}$ \\
\hline & Round 3 Question: \\
\hline & $\begin{array}{l}\text { Recently, there has been a lot of } \\
\text { attention around companies that use } \\
\text { apps and websites to convey work and } \\
\text { services. This is usually called the } \\
\text { sharing economy. }\end{array}$ \\
\hline & $\begin{array}{l}\text { During the last } 12 \text { months, you have } \\
\text { done some of the following... }\end{array}$ \\
\hline & $\begin{array}{l}\text { 1. Did you work as a bicycle courier } \\
\text { for Foodora? } \\
\text { 2. Worked as a cleaner for WeClean? } \\
\text { 3. Worked for Upwork or Konsus? } \\
\text { 4. Worked as a driver for Haxi? } \\
\text { 5. Did a job you found on FINN } \\
\text { småjobber? } \\
\text { 6. Did you do a job on Mitt anbud.no? } \\
\text { 7. Rented a home on Airbnb? } \\
\text { 8. Done assignments you have found } \\
\text { on other apps or websites } \\
\text { 9. None of the aforementioned }\end{array}$ \\
\hline
\end{tabular}


Borini \& Rinne (2017)

CIPD (2017)
Eurobarometer (2016)
Even if you are not doing it now, have you ever done work in exchange for money, for orders that you received over the Internet or an app?

Thinking about the LAST 12 MONTHS, which, if any, of the following have you done via an online platform (i.e. website) or app (i.e. mobile device application) to earn money? (Please tick all that apply)

Provided transport using my vehicle (e.g. Uber, BlaBlaCar etc)

Rented out my vehicle (e.g. EasyCar, Zipcar etc)

Rented/shared my accommodation (e.g. AirBnB, tripping, HomeAway etc)

Delivered food or goods (e.g. Deliveroo, City Sprint)

Performed short-term jobs via online platforms that $\mathrm{c}$ onnect people looking for services (e.g. TaskRabbit, Upwork, PeoplePerHour etc)

Sold things I have created via online platforms (e.g. Etsy)

Other work arranged through an online platform (open)

Still thinking about the LAST 12 MONTHS, what contribution did the following type of work make towards the total income you received from paid work over the past year?

Provided transport using my vehicle (e.g. Uber, BlaBlaCar etc)

Rented out my vehicle (e.g. EasyCar, Zipcar etc)

Delivered food or goods (e.g. Deliveroo, City Sprint)

Performed short-term jobs via online platforms that connect people looking for services (e.g. TaskRabbit, Upwork, PeoplePerHour etc)

Other work arranged through an online platform

A collaborative platform is an internet based tool that enables transactions between people providing and using a service. They can be used for a wide range of services, from renting accommodation and car sharing to small household jobs.

Have you ever provided services on these platforms?

No, you haven't. 1

You have offered a service on one or more of these platforms once 2

You offer services via these platforms occasionally (once every few months) 3

You offer services via these platforms regularly (every month) 4 
Farrell, D. and F. Greig (2016), Paychecks, Paydays, and the Online Platform Economy - Big Data on Income Volatility.

Farrell, D. and F. Greig (2018), The Online Platform Economy in 2018, Drivers, Workers, Sellers, and Lessons. https://www.jpmorganchase.com/corporate/institute/document/instituteope-2018.pdf

Huws, U., N. Spencer and S. Joyce (2016), Crowd Work in Europe: Preliminary results from a survey in the UK, Sweden, Germany, Austria and the Netherlands.

Katz L. and Krueger A. (2016), The Rise and Nature of Alternative Work Arrangements in the United States, 1995-2015

Manyika, J. et al. (2016), Independent work: Choice, necessity, and the gig economy

Pesole, A. et al. (2018), Platform Workers in Europe, Publications Office of the European Union

Pew Research Center (2016), Gig Work, Online Selling and Home Sharing.
Other 5

None 6

DK/NA 7

No questions. Based directly on income flows originating from a selection of platforms. In 2016, 42 platforms were selected.

128 platforms were selected, based on 3 key criteria: platforms i/ connect independent suppliers directly with demanders, ii/ mediate payment, and iii/ empower participants to enter and leave the market whenever they want.

No questionnaire in the report published.

Do you do direct selling to customers on your main job or a secondary job, or both?

Does your direct selling involve goods or services?

Do you work with an intermediary, such as Avon or Uber, in your direct selling activity?

Do you work with an online intermediary to find customers, such as Uber or TaskRabbit?

Detailed questionnaire not provided.

Has the respondent ever gained income from:

providing services via online platforms, where you and the client are matched digitally, payment is conducted digitally via the platform and the work is location-independent, web-based; or

providing services via online platforms, where you and the client are matched digitally, and the payment is conducted digitally via the platform, but work is performed on-location

Some people find paid jobs or tasks by connecting directly with people who want to hire them using a particular type of website or mobile app. These sites require workers to create a user profile in order to find and accept assignments, and they also coordinate payment once the work is complete. In the last year, have you earned money by taking on jobs through this type of website or mobile app (for example, by driving someone from one place to another, cleaning someone's home, or doing online tasks)? $(\mathrm{Y} / \mathrm{N})$ What sorts of jobs or tasks have you performed in the last year using these 
SOU (2017)

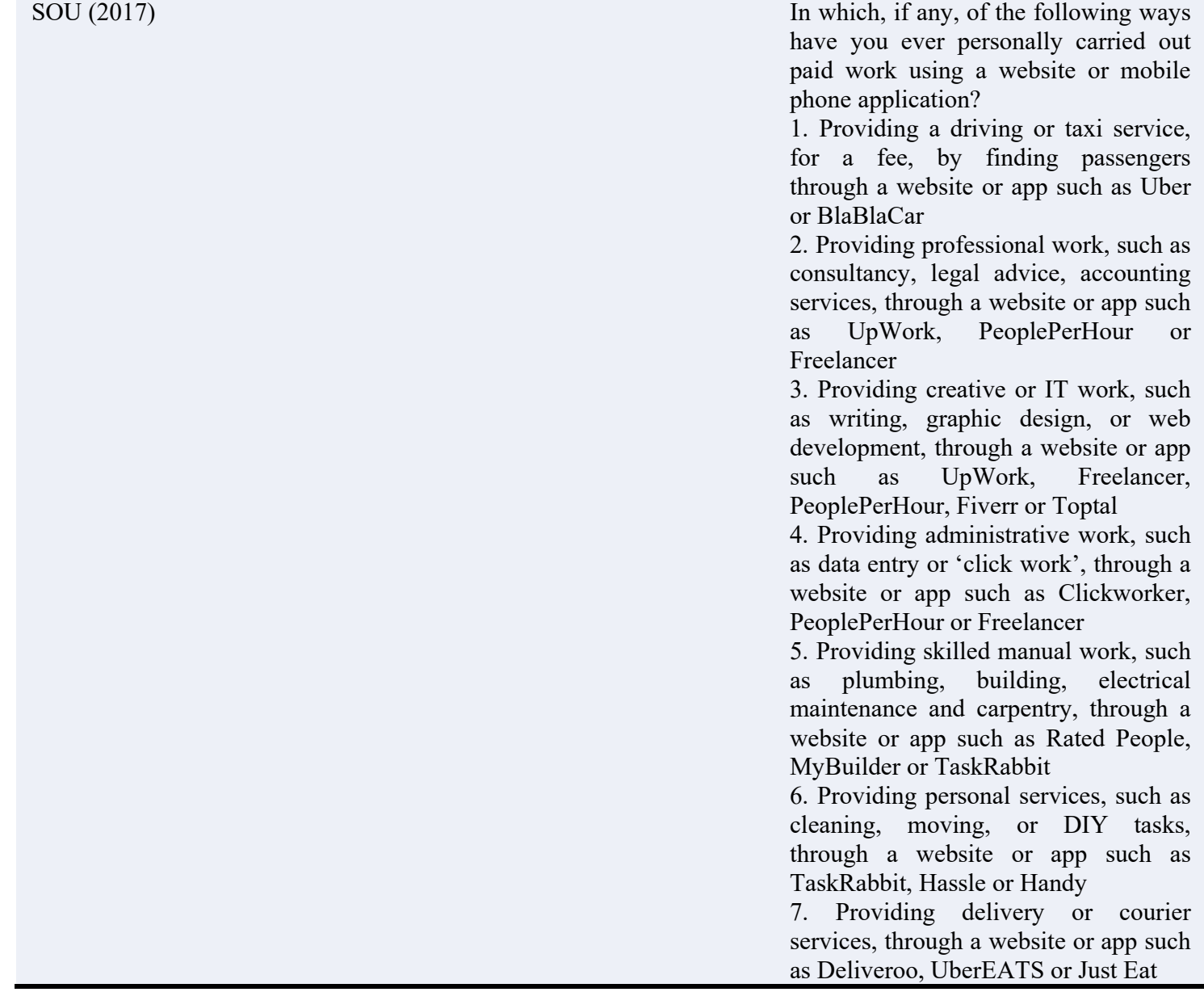

services?

Driving for a ride-hailing app (such as Uber or Lyft)6

Shopping for or delivering household items

Performing tasks online (like completing surveys or doing data entry)

Cleaning someone's home or doing laundry

Something else

In which, if any, of the following ways have you ever personally carried out paid work using a website or mobile phone application?

Providing a driving or ta

3. Providing creative or IT work, such as writing, graphic design, or web development, through a website or app PeoplePerHour, Fiverr or Toptal

4. Providing administrative work, such as data entry or 'click work', through a website or app such as Clickworker, 5. Providing skilled manual work, such as plumbing, building, electrical maintenance and carpentry, through a . TaskRabbit, Hassle or Handy as Deliveroo, UberEATS or Just Eat 


\section{Annex Table 1.A.2. Questions posed in official surveys}

\begin{tabular}{|c|c|}
\hline Survey & Questions \\
\hline $\begin{array}{l}\text { Canada LFS (LFS Fast } \text { Track } \\
\text { Module } \quad \text {-October } \quad 2016 \\
\text { collection) }\end{array}$ & $\begin{array}{l}\text { In the past } 12 \text { months, did you offer ride services such as Uber, Lyft, } \\
\text { etc.? } \\
\text { In the past } 12 \text { months, did you offer private accommodation services } \\
\text { such as Airbnb, Flipkey, etc.? }\end{array}$ \\
\hline $\begin{array}{l}\text { Canada Internet Use Survey } \\
\text { (2018 survey, forthcoming) }\end{array}$ & $\begin{array}{l}\text { Online work } \\
\text { During the past } 12 \text { months have you used the Internet to earn income? } \\
\text { (Y / N) } \\
\text { Include money made through online bulletin boards } \\
\text { If Yes: } \\
\text { What type of income was this? } \\
\text { Was it a: Main source of income / Additional source of income } \\
\text { Through what method did you earn this income during the past } 12 \\
\text { months? } \\
\text { Select all that apply. } \\
\text { Was it through: } \\
\text { Online bulletin board for physical goods (e.g., Etsy, Kijiji, Ebay) } \\
\text { Online bulletin board for services (e.g., Kijiji, Craigslist) / Platform- } \\
\text { based peer-to-peer services (e.g., Uber, Airbnb, AskforTask) / Online } \\
\text { freelancing (e.g., Upwork, Freelancer, Catalant, Proz, Fiverr) / Crowd- } \\
\text { based microwork (e.g., Amazon Mechanical Turk, Cloudflower) / } \\
\text { Advertisement-based income (e.g., income earned through YouTube or } \\
\text { personal blogs) / Other } \\
\text { What is your best estimate of the total income you earned through the } \\
\text { Internet during the past } 12 \text { months? } \\
\text { Would you say: Less than USD } 200 / \text { USD } 200 \text { to less than USD } 1000 / \\
\text { USD } 1000 \text { to less than USD } 10000 \text { /USD } 10000 \text { to less than } \\
\text { USD } 20000 \text { / USD } 20000 \text { to less than USD } 50000 / \text { USD } 50000 \text { or } \\
\text { more }\end{array}$ \\
\hline Denmark LFS & $\begin{array}{l}\text { Have you earned money in the past } 12 \text { months by performing work done } \\
\text { through websites or apps - for example, via Uber? (Y / N) } \\
\text { In the past } 12 \text { months, have you earned money by renting your property } \\
\text { or your property through websites or apps for example via Airbnb? (Y / } \\
\mathrm{N})\end{array}$ \\
\hline $\begin{array}{l}\text { Eurostat, Community Survey } \\
\text { on ICT Usage and e-commerce } \\
\text { in Households and by } \\
\text { Individuals, } 2018\end{array}$ & $\begin{array}{l}\text { B8. Have you obtained paid work by using an intermediary website or } \\
\text { apps (e.g. Upwork, TaskRabbit, Freelancer, Amazon Mechanical Turk) } \\
\text { in the last } 12 \text { months? } \\
\text { Websites of employment agency are excluded } \\
\text { If YES to B8 go to B8.1, otherwise C1 } \\
\text { B8.1. If Yes to B8: Could you please specify if the income of this work } \\
\text { is: } \\
\text { a) the main source of your income } \\
\text { b) an additional source of income }\end{array}$ \\
\hline Finland LFS & $\begin{array}{l}\text { Have you during the past } 12 \text { months worked or otherwise earned income } \\
\text { through the following platforms: 1. Airbnb, } 2 \text {. Uber, } \\
\text { 3. Tori.fi/Huuto.net, 4. Solved, 5. Some other, } 6 \text {. None of the above. }\end{array}$ \\
\hline $\begin{array}{l}\text { France LFS (Ad Hoc Module } \\
\text { 2017) }\end{array}$ & $\begin{array}{l}\text { How do you mainly get in touch with your clients? } \\
\text { Many answers possible (if the respondent can't choose) } \\
\text { Don't read item } 5 \text {. } \\
\text { 1. Clients come into the shop or contact you directly (phone, mail, } \\
\text { Internet etc.) } \\
\text { 2. Clients go through a platform or through a third party business that } \\
\text { redirect them to you. } \\
\text { 3. You're directly looking for clients / contact yourself the clients. } \\
\text { 4. Other } \\
\text { 5. Not meaningful }\end{array}$ \\
\hline Swiss LFS & $\begin{array}{l}\text { Today, internet platforms and mobile applications offer new revenue } \\
\text { opportunities. In these cases, we are put in touch with the customer and } \\
\text { we are usually paid directly via the platform. }\end{array}$ \\
\hline
\end{tabular}


US CPS Computer Internet Use Supplement

US Federal Reserve (2018), Survey of Households Economics and Decisionmaking (SHED).

Bureau of Labor Statistics, May 2017 Contigent Worker Supplement

\section{UK ONS}

(cognitive/qualitative pilot of questions for digital platform)
In the last 12 months, have you rented a room, an apartment or a house via an internet platform or mobile application, such as Airbnb or Flipkey?

In the last 12 months, have you provided taxi services via an internet platform or mobile application, such as Uber or Lyft?

In the last 12 months, have you sold goods via an internet platform or mobile application, such as for example Ricardo or Ebay? Do you answer" yes "only if they are goods that you bought or collected in the purpose of reselling them.

In the last 12 months, have you provided other services via an internet platform or mobile application, such as cleaning or manual work, delivery services or online programming?

Did you provide any of these paid services via an internet platform or mobile application last week?

and Have you offered own services for sale via the Internet (Examples include offering rentals on Airbnb and driving for Uber or Lyft. Do not include any goods or possessions sold online, such as clothing, shoes, or crafts.)

In the past month, have you been paid for each of the following online occasional work activities or side jobs?

Please do not include activities that you only do as part of your main job

a. Completing paid online tasks, such as on Amazon Services, Mechanical Turk, Fiverr, Task Rabbit, or YouTube. (Y/N)

b. Renting out property online, such as your car, your place of residence, etc. $(\mathrm{Y} / \mathrm{N})$

c. Selling goods on-line through eBay, Craigslist, or other websites $(\mathrm{Y} / \mathrm{N})$

d. Driving using a ride-sharing app such as Uber or Lyft. (Y/N)

e. Other online paid activities (do not include taking GfK Surveys). $(\mathrm{Y} / \mathrm{N})$

Some people find short, IN-PERSON tasks or jobs through companies that connect them directly with customers using a website or mobile app. These companies also coordinate payment for the service through the app or website. For example, using your own car to drive people from one place to another, delivering something, or doing someone's household tasks or errands. Does this describe ANY work you did LAST WEEK? Y/N

Was that for your main job, your second job, or other additional work for pay?

Main job

Second job

Additional work for pay

Some people select short, ONLINE tasks or projects through companies that maintain lists that are accessed through an app or a website. These tasks are done entirely online and the companies coordinate payment for the work. For example, data entry, translating text, web or software development, or graphic design. Does this describe ANY work you did LAST WEEK? Y/N

Was that for your main job, your second job, or other additional work for pay?

Main job

Second job

Additional work for pay

In the last 12 months have you used a digital platform to find work on a short term, payment by task basis?

Does the work you found on a digital platform provide your main source of earnings over the past three months? 